\title{
EFFICIENCY VS THE MAQASID SHARIAH INDEX: A COMPARATIVE STUDY OF CONVENTIONAL AND ISLAMIC BANKS IN INDONESIA
}

\author{
Salman Al Parisi ${ }^{* 1}$, Idqan Fahmi*), and Trias Andati**) \\ *) School of Business, IPB University \\ Jl. Padjajaran, Bogor, Indonesia 16151, Indonesia \\ $\left.{ }^{* *}\right)$ PPM Jakarta \\ Jl. Menteng Raya No.9 Menteng, Jakarta 10340, Indonesia
}

\begin{abstract}
Over the last few years, Indonesian Islamic banking has experienced positive development, but there has been a dramatic dip in the growth of the assets and deposits of commercial Islamic banks. This indicates possible inefficiencies in these banks, and the sharp decline in the growth of their assets needs to be assessed in terms of efficiency and Islamic values, which are considered to be able to enhance performance. This research examines conventional and Islamic bank performance in terms of efficiency with data envelopment analysis (DEA) and the maqasid shariah index (MSI) with simple additive weighting (SAW) analysis, using data from fourteen commercial Islamic banks and four commercial conventional banks over the period 2007 to 2018. The results show that conventional banks were more efficient than Islamic ones, except in the financial crisis period, when the efficiency of Islamic banks was higher. In addition, the maqasid shariah index of conventional banks was lower than that of Islamic ones, although the index for Islamic banks was still very low. Furthermore, the study also found that the greater the level of total assets, the higher the maqasid shariah.
\end{abstract}

Keywords: banking performance, commercial islamic banks, efficiency, maqasid shariah index

\begin{abstract}
Abstrak: Selama beberapa tahun terakhir, perbankan syariah Indonesia telah mengalami perkembangan yang positif, namun tren pertumbuhan aset dan DPK Bank Umum Syariah (BUS) terus mengalami penurunan yang signifikan. Hal ini mengindikasikan kemungkinan inefisiensi pada Bank Umum Syariah (BUS), dan penurunan yang tajam pada pertumbuhan asetnya perlu dievaluasi dari sisi efisiensi dan nilai-nilai syariah, yang dinilai mampu meningkatkan kinerja. Penelitian ini mengkaji kinerja bank konvensional dan syariah melalui pendekatan efisiensi dengan data envelopment analysis (DEA) dan Indeks Maqasid Syariah (IMS) dengan analisis simple additive weighting (SAW) menggunakan data dari empat belas Bank Umum Syariah dan empat Bank Umum Konvensional selama periode 2007 hingga 2018. Hasil penelitian menunjukkan bahwa bank konvensional lebih efisien daripada bank syariah, kecuali pada saat krisis keuangan, efisiensi Bank Syariah lebih tinggi dibandingkan Bank Konvensional. Penelitian ini juga menyatakan bahwa IMS Bank Konvensional lebih rendah daripada Bank Syariah, meskipun demikian IMS Bank Syariah masih sangat rendah. Selain itu, studi ini juga menemukan bahwa semakin besar total aset, semakin tinggi implementasi maqasid syariah pada kelompok Bank Umum Syariah.
\end{abstract}

Kata kunci: kinerja perbankan, bank umum syariah, efisiensi, indeks maqasid syariah

\footnotetext{
${ }^{1}$ Corresponding author:

Email: salman.al.farisi.tazkia@gmail.com
} 


\section{INTRODUCTION}

The global Islamic financial market continues to experience a positive trend, driven by growing public demand for the halal industry sector. The assets of the Islamic financial industry grew by 8.3 percent, and the contribution Islamic banking reached 71 percent of the assets of the global Islamic financial industry (GlobeNewswire Research and Market, 2019). Islamic banking is projected to grow gradually, especially in Muslim majority countries, triggered by the estimated growth of the Muslim population, which is expected to reach 2.3 billion by 2030 (Olson and Zoubi, 2016).

There are various factors that motivate people to choose Islamic banks as an alternative instrument for financial transactions. First, Islamic banks are considered to have stronger resilience than conventional ones in the face of the global financial crises (Beck et al. 2010; Čihák and Hesse, 2010; Rosman et al. 2014; Olson and Zoubi, 2016). Islamic banks are able to be a substitution of conventional ones when the crisis period (Widokartiko et al, 2016). Second, the unique characteristics of Islamic banks, such as the profit loss sharing (PLS) system and the prohibition of maysir (gambling), gharar (uncertainty), and riba (interest) in their business activities intends to promote justice between the parties involved (Antonio, 2001). Moreover, the practices of maysir, gharar and riba were said to be major factors leading to the financial crisis (Ahmed, 2010). Third, Islamic banks have been able to boost economic growth and financial inclusion (Imam and Kpodar, 2016). Furthermore, the practices of Islamic banking adopted by either Islamic or non-Islamic countries in their banking regulations might also assist the growth (Imam and Kpodar, 2016).

Indonesian Islamic banking consists of 14 commercial Islamic banks (BUS), 20 Islamic business units (UUS) and 165 Islamic rural banks (BPRS). The composition of Indonesian Islamic banking assets is dominated by Islamic commercial banks (BUS), at 64.62 percent, followed by Islamic business units (UUS) at 32.86 percent, and Islamic rural banks (BPRS) at 2.52 percent (OJK, 2019). Islamic banking has experienced positive development over the past five years, but there has been a dramatic dip in the growth of the assets and deposits of commercial Islamic banks, of 5.93 percent and 6.79 percent respectively, as of November 2019, whereas Indonesian Islamic finance has been ranked first in the global Islamic financial market (GIFR, 2019). Based on these facts, the performance of commercial Islamic banks needs to be evaluated comprehensively. The situation indicates that they are facing inefficiencies, which is also shown by their operating costs to operating income (BOPO) ratio, reach by 84.45 percent. However, this was still higher than that of commercial conventional banks (BUK), which was only 79.39 percent in 2019 . The main strategic issues of commercial Islamic banks in Indonesia were efficiency and funding structure, as reflected in cash and saving accounts (CASA) (OJK, 2019). Commercial Islamic banks are still not as efficient as their conventional counterparts, so need to be assessed in terms of efficiency, which can be defined by input and output approaches. Efficiency is closely related to the vision of developing Indonesian Islamic banking.

Theconceptofefficiencyoriginated frommicroeconomic theory, namely producer and consumer theory (Ascarya and Yumanita, 2006). Measuring economic efficiency was associated with the use of frontier functions, using both parametric and non-parametric approaches (Murillo and Zamorano, 2004). The production frontier line was employed to elaborate the relationship between input and output in the production process and to describe the achievement of the maximum output level of each input and technology used (Coelli et al. 2005). Efficiency is identified by the way companies obtain the maximum level of output with a certain number of inputs (Farrell, 1957). The efficency rate of each business unit can be measured. It is efficient if it is valued at 100 percent; if the value is lower than 100 percent, then it is not efficient (Debreu, 1951).

Efficiency measurement can be conducted using two methods, namely parametric and nonparametric approaches (Murillo and Zamorano, 2004). The parametric approach can be analysed by stochastic frontier analysis (SFA), the distribution free approach (DFA), and the thick frontier approach (TFA), while the nonparametric approach generally uses data envelopment analysis (DEA) and the free disposal hull (FDH). Efficiency has been divided into two approach orientations, namely those of output and input (Coelli et al. 2005). Measurement of DEA efficiency consists of three approaches, namely asset, production and intermediation (Freixas and Rochet, 1998).

Studies on Islamic banking efficiencies have been conducted worldwide (Kamarudin et al. 2019; Mezzi, 2018; Miah and Uddin, 2017; Alqahtani et al. 2017; 
Majeed and Zanib, 2016; Wanke et al. 2016; Sufian and Kamarudin, 2015; Rosman et al. 2014; Ftiti et al. 2013; Ismail et al. 2013; Rozzani and Rahman, 2013; Mostafa, 2011; Ahmad and Noor, 2010). In Indonesia, there have also been several studies on Islamic banking efficiencies (Hidayati et al. 2017; Hardianto and Wulandari, 2016; Puteh et al. 2018; Havidz and Setiawan, 2015; Firdaus and Hosen, 2013; Ascarya and Yumanita, 2008). Most of these have been concerned with comparisons between Islamic and conventional bank efficiency. The results of the studies show that conventional banks are more efficient than Islamic ones. However, performance measurement is considered to be insufficiently fair if Islamic banks are compared to conventional ones only in terms of efficiency, which is a conventional measurement. Other studies only analysed Islamic bank efficiency in isolation, particularly those from Indonesia. The studies do not show the real position of Islamic banks in the banking industry without a comparison with conventional ones, because Data Envelopment Analysis (DEA) measurement is based on relative efficiency.

Apart from measuring efficiency, the sharia characteristics which are inherent in Islamic bank operations cannot be separated (Ullah, 2014; Ullah and Khanam, 2018). Sharia values and mashlahah, as a form of benefits and blessings, are considered able to encourage commercial Islamic banks to be efficient, and to promote economic growth and the equity of public welfare (Chapra, 1993). The higher the sharia values in Islamic banks, the higher their financial performance (Reza and Violita, 2018). Therefore, Islamic banking performance needs to be assessed in terms of efficiency and its sharia value approach.

The essence of sharia values can be reflected in the implementation of al-maqasid al-shariah. This is formed of two words, maqasid and shariah: maqasid means things that are desired and intended, while shariah means that the way to the source of life (Elahi, 2010). Scholars define maqasid shariah in terms of bringing benefits (jalb al-mashalih), and leaving damage (almafāsid) (Khalaifì, 2004).

The maintenance of maqasid shariah aspects in human life could improve human quality and socio-economic justice, and accelerate economic growth, which is a consequence of an increase infinancial performance (Chapra, 1993). The implementation of sharia principles and values simultaneously will bring benefits and blessings (P3EI UII-Bank Indonesia, 2009). Several studies have used the maqasid shariah index (MSI) to measure Islamic banking performance (Ibrahim and Ismail, 2020; Rusydiana and Parisi, 2016; Mohammed and Taib, 2015; Antonio et al. 2012).

Based on this background of the study, it can be assumed that BUS in Indonesia has not operated efficiently except in crisis period due to its business characteristic which will be estimated using DEA method and the implementation of Maqasid Shariah Index (MSI) of BUS in Indonesia is still low which will be estimated using SAW method.

This study aims to analyze efficiency and the MSI simultaneously in relation to fourteen commercial Islamic banks and four commercial conventional banks in Indonesia, which are discussed in four sections: the introduction, methods, results and discussion, and conclusions and recommendations.

\section{METHODS}

This research was conducted from August 2019 to March 2020. The data that we used were secondary data from commercial Islamic bank and selected conventional one. Secondary data is data that contains information collected from other sources which are ready to be processed (Sumarwan et al. 2018). The data were considered as numerical data, which derived from the annual report of each bank and OJK website. They were taken from the financial report that published annually from 2007 to 2018. Furthermore, this study used purposive sample to analyze Islamic bank performance, both efficiency and maqasid shariah index approaches. The sample consisted of all commercial Islamic banks, namely; Bank Aceh Syariah (BAS), Bank NTB Syariah (BNTBS), Bank Muammalat Indonesia (BMI), Bank Victoria Syariah (BVS), BRI Syariah (BRIS), Bank Jabar Banten Syariah (BJBS), BNI Syariah (BNIS), Bank Syariah Mandiri (BSM), Bank Mega Syariah (MEGAS), Bank Panin Dubai Syariah (PANS), Bank Syariah Bukopin (BSB), BCA Syariah (BCAS), BTPN Syariah (BTPNS), and Bank Maybank Syariah Indonesia (MAYS), and the four greatest assets of commercial conventional ones in Indonesia, namely; Bank Rakyat Indonesia (BRI), Bank Mandiri, Bank Central Asia (BCA), and Bank Negara Indonesia (BNI). Commercial Islamic banks could be a representation of Islamic bank, which dominated the composition of 
Indonesian Islamic bank assets. In addition, the use of sample of the largest four conventional banks in this study was to obtain a more accurate efficiency score, because the nature of data envelopment analysis (DEA) was best practice and relatively.

There were two methods which employed in this research; first, data envelopment analysis (DEA). DEA was introduced by Charnes et al. (1978) and Banker et al. (1984) which often referred to as CCR and BCC models. DEA is a mathematical program optimization method that measures the technical efficiency of a Decision Making Unit (DMU) by comparing it to other DMUs relatively by using the same types of input and output variables (Sutawijaya and Lestari, 2009). DEA was used to calculate the efficiency scores, which produced scores between 0 and 1 (Firdaus and Hosen, 2013). This study used DEA with an intermediation approach, which was introduced by Sealey and Lindley (1977), that was in accordance with the characteristics of Islamic banks (Brown et al, 2007). The input and output variables used refer to the study of Firdaus and Hosen (2013), namely; deposits, labour costs and total assets were used as inputs, while credit/financing and total operating income represented outputs, furthermore, this study used input orientation, the CCR model (Charnes et al. 1978) and the BCC model (Banker et al. 1984).

Second, simple additive weighting (SAW) method is a concept that has been determined and measured by Mohammed and Taib (2015) which refer to Abu Zahrah's maqasid theory. There were three main objects or concepts used to determine the maqasid shariah index of a bank. The concepts were taken from the maqasid shariah of Abu Zahrah (2008), namely; educating individuals, establishing justice, and achieving mashlahah. This method measured a concept that was still abstract by breaking the concept into an observable character which called a dimension. There were nine dimensions, namely advancement of knowledge (D1), instilling new skills and improvements (D2), creating awareness of Islamic banking (D3), fair returns (D4), cheap products and services (D5), elimination of negative elements that breed injustices (D6), profitability (D7), redistribution of income and wealth (D8), and investment in vital real sector (D9). Then, the dimension was broken down into something that could be measured which called an element. There were ten elements, namely education grant (E1), research (E2), training (E3), publicity (E4), fair returns
(E5), functional distribution (E6), interest free product (E7), profit ratios (E8), personal income (E9), and investment ratios in real sector (E10). The weighting of concepts and elements have been determined by Mohammed and Taib (2015) which obtained from interviews with 16 shariah experts. SAW method was employed to calculate maqasid shariah index (MSI), which produced index scores between 0 and 1 .

In the first step of analysis, DEA was employed, which produced the values of technical efficiency (TE), pure technical efficiency (PTE), and scale efficiency (ES), together with the simple additive weighting (SAW) method, which produced the maqasid shariah index (MSI). In the second step, the performance of commercial Islamic banks and conventional ones in the terms of efficiency and the implementation of maqasid shariah index was compared. From the results of this research, it was expected to obtain policy implications to improve Islamic banks performance, which has not operated efficiently and still low of implementation of Maqasid Shariah. Moreover, the software used in the analysis was Microsoft Excel 2016, Banxia Frontier Analyst 3, and SPSS 21.

\section{RESULTS}

\section{Comparison of Efficiency between Islamic and Conventional Banks}

Differences were found in the study in the level of efficiency of the banks. Efficiency analysis produced a technical efficiency score (TE), a pure technical efficiency score (PTE), and a scale efficiency score (SE). A bank was deemed to be efficient if the value was 100 percent, but inefficient if it was lower than 100 percent.

Table 1 shows that only 6.6 percent of all banks (Islamic and conventional) were fully efficient in TE, PTE and SE over the study period. In general, only 14 percent of commercial Islamic banks (BUS) operated efficiently, with the remainder inefficient, 65 percent of which operated with increasing returns to scale (IRS), and 20 percent with decreasing returns to scale (DRS). In addition, only 23 percent of commercial conventional banks (BUK) operated efficiently, with the remaining 77 percent experiencing increasing returns to scale (IRS). These findings indicate that the efficiency of 
BUK was better than that of BUS. The results are in line with those of previous studies (Miah and Uddin, 2017; Alqahtani et al. 2017; Majeed and Zanib, 2016; Ismail et al. 2013; Rozzani and Rahman, 2013).

Table 1 also indicates that average BUS efficiency was higher than that of BUK in crisis period (in 2008). The results are in line with the initial hypothesis and previous studies (Olson and Zoubi, 2016; Rosman et al. 2014). However, after the crisis period, commercial conventional banks became more efficient than commercial Islamic ones. The results are strengthened by those of the study of Hardianto and Wulandari (2016).

BUS needs to increase its total assets in order to expand its business scale. Total assets represent all aspects of a bank's growth (Kim and Haleblian, 2011). The greater the total assets owned by BUS, the bigger the economic scale of BUS, this can be expected to increase its efficiency through minimizing operational costs. The slowing and declining growth of BUS was influenced by the small total assets. Total assets of commercial banks have reached 8,212,586 billion Rupiah, those still far behind when compared to BUS which still reached 350,364 billion Rupiah (OJK, 2019).

Table 2 shows the average efficiency level of the fourteen BUS and four BUK during the 2007-2018 period. Bank NTB Syariah achieved the highest efficiency score, and was able to achieve a net profit of 3.68 percent (yoy) in 2018. This achievement is inseparable from the policy of the bank, which focuses on cost efficiency and revenue optimisation. On other hand, 11 commercial Islamic banks were operating with IRS, while the other two were operating with DRS.

Bank Victoria Syariah was the commercial Islamic bank with the lowest technical efficiency score. It was in a decreasing returns to scale (DRS) situation, with an average RTS of -0.875 . This result is inseparable from the CASA (cash and saving accounts) funds, which were not optimal to meet targets above 10 percent of its total deposits. In addition, it was strengthened by its low market share, which was only 0.45 percent in 2018. Suboptimal performance has implications for operational losses.

Table 1. Efficiency of Commercial Islamic and Conventional Banks

\begin{tabular}{|c|c|c|c|c|c|c|c|c|c|c|c|c|}
\hline CCR Model (TE) & 2007 & 2008 & 2009 & 2010 & 2011 & 2012 & 2013 & 2014 & 2015 & 2016 & 2017 & 2018 \\
\hline Number of Banks & 7 & 8 & 9 & 13 & 15 & 15 & 15 & 16 & 16 & 17 & 17 & 18 \\
\hline Number of Efficient Banks & 1 & 0 & 1 & 0 & 2 & 1 & 0 & 0 & 1 & 0 & 1 & 4 \\
\hline Average BUS Efficiency & 93.66 & 69.50 & 78.08 & 69.56 & 70.81 & 74.85 & 76.24 & 77.70 & 80.59 & 76.71 & 67.65 & 74.64 \\
\hline Average BUK Efficiency & 60.87 & 66.32 & 67.08 & 68.79 & 71.39 & 73.11 & 77.09 & 77.57 & 79.56 & 78.71 & 79.18 & 82.25 \\
\hline Average Bank Efficiency & 74.92 & 67.91 & 73.19 & 69.33 & 70.97 & 74.38 & 76.47 & 77.67 & 80.33 & 77.18 & 70.37 & 76.33 \\
\hline$\%$ of Inefficient Banks & $86 \%$ & $100 \%$ & $89 \%$ & $100 \%$ & $87 \%$ & $93 \%$ & $100 \%$ & $100 \%$ & $94 \%$ & $100 \%$ & $94 \%$ & $78 \%$ \\
\hline BCC Model (PTE) & 2007 & 2008 & 2009 & 2010 & 2011 & 2012 & 2013 & 2014 & 2015 & 2016 & 2017 & 2018 \\
\hline Number of Banks & 7 & 8 & 9 & 13 & 15 & 15 & 15 & 16 & 16 & 17 & 17 & 18 \\
\hline Number of Efficient Banks & 2 & 2 & 2 & 2 & 4 & 4 & 1 & 1 & 1 & 1 & 2 & 6 \\
\hline Average BUS Efficiency & 96.36 & 86.44 & 85.04 & 82.82 & 82.26 & 84.92 & 86.79 & 86.46 & 88.64 & 85.46 & 77.97 & 82.26 \\
\hline Average BUK Efficiency & 72.12 & 78.55 & 79.28 & 81.15 & 85.37 & 88.49 & 92.73 & 92.32 & 93.09 & 92.88 & 93.73 & 97.34 \\
\hline Average Bank Efficiency & 82.51 & 82.49 & 82.48 & 82.31 & 83.09 & 85.87 & 88.37 & 87.92 & 89.75 & 87.20 & 81.68 & 85.61 \\
\hline$\%$ of Inefficient Banks & $71 \%$ & $75 \%$ & $78 \%$ & $85 \%$ & $73 \%$ & $73 \%$ & $93 \%$ & $94 \%$ & $94 \%$ & $94 \%$ & $88 \%$ & $67 \%$ \\
\hline Scale Efficiency (SE) & 2007 & 2008 & 2009 & 2010 & 2011 & 2012 & 2013 & 2014 & 2015 & 2016 & 2017 & 2018 \\
\hline Number of Banks & 7 & 8 & 9 & 13 & 15 & 15 & 15 & 16 & 16 & 17 & 17 & 18 \\
\hline Number of Efficient Banks & 1 & 0 & 1 & 0 & 2 & 1 & 0 & 0 & 1 & 0 & 1 & 4 \\
\hline Average BUS Efficiency & 96.98 & 82.57 & 91.90 & 85.25 & 86.66 & 87.85 & 88.32 & 89.95 & 90.76 & 89.74 & 86.41 & 90.04 \\
\hline Average BUK Efficiency & 82.70 & 83.25 & 83.56 & 83.64 & 82.78 & 82.08 & 82.83 & 83.71 & 85.12 & 84.41 & 84.20 & 84.37 \\
\hline Average Bank Efficiency & 88.82 & 82.91 & 88.20 & 84.76 & 85.63 & 86.31 & 86.85 & 88.39 & 89.35 & 88.49 & 85.89 & 88.78 \\
\hline$\%$ of Inefficient Banks & $86 \%$ & $100 \%$ & $89 \%$ & $100 \%$ & $87 \%$ & $93 \%$ & $100 \%$ & $100 \%$ & $94 \%$ & $100 \%$ & $94 \%$ & $78 \%$ \\
\hline
\end{tabular}




\section{Comparison of the Islamic and Conventional Banks' Maqasid Shariah Index}

The performance measurement of the MSI was classified into three main objectives, namely (1) educating individuals, (2) upholding justice, and (3) mashlahah (benefit and blessing). The results can be seen in Table 3. Based on the calculations, it can be concluded that Bank Panin Syariah was that with the highest MSI, and the lowest being Maybank Syariah. These results are in line with the previous study of Sudrajat and Sodiq (2016). In the conventional bank group, Bank Central Asia (BCA) had the highest MSI, followed by Bank Rakyat Indonesia (BRI), Bank Negara Indonesia (BNI), and Bank Mandiri.

The average MSI of commercial Islamic banks was 0.271. Eight BUS had MSI scores above the average, namely Bank Panin Syariah (PANS), Bank Muamalat Indonesia (BMI), Bank Syariah Mandiri (BSM), BRI Syariah (BRIS), BNI Syariah (BNIS), BCA Syariah (BCAS), Bank Victoria Syariah (BVS) and Bank Aceh Syariah (BAS). These also had the highest market share among Islamic banks: BSM (20.60 percent), BMI (12.00 percent), BNIS (8.60 percent), BRIS (7.94 percent), BAS (4.84 percent), PANS (1.84 percent), and BCAS (1.48 percent). These results indicate that the greater the total assets, the higher the maqasid shariah index. Higher total assets owned by Islamic banks could also encourage the implementation of maqasid shariah among them. In addition, the average MSI of commercial conventional banks was 0.099, meaning the MSI of BUS was higher than that of BUK. This results are in accordance with the business operations of Islamic banks, which should be based on sharia values, in contrast to conventional banks, which operate on conventional principles. Despite the MSI of Islamic banks being higher than that of conventional ones, it is still relatively low, at 0.271 on a scale of 1.000 . These results are in line with the study of Hartono and Sobari (2017). Consequently, Islamic Banks should improve their performance in terms of maqasid shariah, which should in turn improve their performance. The implementation of Islamic values by Islamic banks is believed to be able to improve their performance (Ullah and Khanam, 2018; Reza and Violita, 2018; Chapra, 1993).
The results in Tables 2 and 3 can be illustrated by the Cartesian diagram as Figure 1. In general, it can be concluded that the higher the MSI, the higher the efficiency level. Quadrant 1 shows the best performance of banks, both in terms of the MSI and efficiency level, and consists of Bank Panin Syariah, Bank Muamalat Indonesia, Bank Syariah Mandiri, BRI Syariah, BTPN Syariah, and Bank NTB Syariah. Quadrant 2 is the group of banks that achieved a low MSI, but their level of efficiency was relatively high, namely Maybank Syariah, BRI, and Bank Mandiri. Quadrant 3 is a group of banks that achieved a low MSI and efficiency level, comprising Bank Mega Syariah, BNI, and BCA. Finally, Quadrant 4 is the group of banks with high MSI performance but relatively low efficiency, these being BNI Syariah, BCA Syariah, Bank Victoria Syariah, Bank Aceh Syariah, Bank Syariah Bukopin, and Bank Jabar Banten Syariah.

\section{Managerial Implications}

Commercial Islamic banks (BUS) have to enhance their total assets to compete with conventional banks in banking industry. The greater the total assets owned by BUS, the bigger the economic scale of BUS. This condition can increase their efficiency by optimizing operational income and minimizing operational costs. In addition, the study indicates that the greater the total assets, the higher the level of maqasid shariah in the Islamic bank group. Consequently, maqasid shariah can also be implemented if Islamic banks have large total assets to expand their outreach in society and their business scale.

\section{CONCLUSION AND RECOMMENDATIONS}

\section{Conclusions}

Commercial conventional banks are more efficient than commercial Islamic ones. However, in the crisis period, the efficiency of Islamic banks was higher than conventional ones. Furthermore, the maqasid shariah index of commercial conventional banks is lower than that of their Islamic counterparts. However, despite the MSI of Islamic banks being higher than that of conventional banks, it is still very low. 
Table 2. Average efficiency of islamic and conventional banks

\begin{tabular}{lcccc}
\hline \multicolumn{1}{c}{ BUS } & TE & PTE & ES & RTS \\
\hline NTBS & 1.0000 & 1.0000 & 1.0000 & CRS \\
BMI & 0.8061 & 0.9205 & 0.8757 & IRS \\
PANS & 0.8247 & 0.9120 & 0.9043 & IRS \\
MAYS & 0.8816 & 0.9103 & 0.9685 & IRS \\
BRIS & 0.7076 & 0.8724 & 0.8111 & IRS \\
BSM & 0.7176 & 0.8492 & 0.8451 & IRS \\
BSB & 0.7400 & 0.8229 & 0.8993 & IRS \\
BNIS & 0.6392 & 0.8048 & 0.7943 & IRS \\
MEGAS & 0.7230 & 0.7980 & 0.9060 & IRS \\
BJBS & 0.7014 & 0.7953 & 0.8819 & IRS \\
BAS & 0.5785 & 0.7314 & 0.7909 & IRS \\
BTPNS & 0.9742 & 0.9744 & 0.9998 & DRS \\
BCAS & 0.6624 & 0.7231 & 0.9160 & DRS \\
BVS & 0.6593 & 0.7741 & 0.8517 & DRS \\
\hline \multicolumn{1}{c}{ BUK } & TE & PTE & ES & RTS \\
\hline BRI & 0.9809 & 0.9972 & 0.9837 & IRS \\
MANDIRI & 0.6986 & 0.9098 & 0.7678 & IRS \\
BNI & 0.6568 & 0.8196 & 0.8014 & IRS \\
BCA & 0.5854 & 0.7424 & 0.7884 & IRS \\
\hline
\end{tabular}

Table 3. Maqasid shariah index of islamic and conventional banks

\begin{tabular}{lcccc}
\hline \multirow{2}{*}{ Bank } & \multicolumn{3}{c}{ Performance Index } & MSI \\
\cline { 2 - 5 } & 1 & 2 & 3 & $(1+2+3)$ \\
\hline PANS & 0.0009 & 0.251 & 0.083 & 0.335 \\
BMI & 0.002 & 0.228 & 0.081 & 0.311 \\
BSM & 0.002 & 0.208 & 0.099 & 0.309 \\
BRIS & 0.002 & 0.201 & 0.085 & 0.288 \\
BNIS & 0.004 & 0.194 & 0.087 & 0.284 \\
BCAS & 0.0011 & 0.224 & 0.059 & 0.284 \\
BVS & 0.0008 & 0.225 & 0.058 & 0.283 \\
BAS & 0.0012 & 0.207 & 0.072 & 0.280 \\
BSB & 0.0014 & 0.199 & 0.067 & 0.267 \\
BJBS & 0.007 & 0.183 & 0.060 & 0.250 \\
BTPNS & 0.003 & 0.178 & 0.063 & 0.244 \\
NTBS & 0.003 & 0.230 & 0.007 & 0.239 \\
MEGAS & 0.0010 & 0.174 & 0.051 & 0.226 \\
MAYS & 0.002 & 0.127 & 0.069 & 0.198 \\
BCA & 0.003 & 0.049 & 0.067 & 0.119 \\
BRI & 0.002 & 0.016 & 0.076 & 0.095 \\
BNI & 0.003 & 0.022 & 0.068 & 0.092 \\
MANDIRI & 0.002 & 0.026 & 0.056 & 0.084 \\
\hline
\end{tabular}

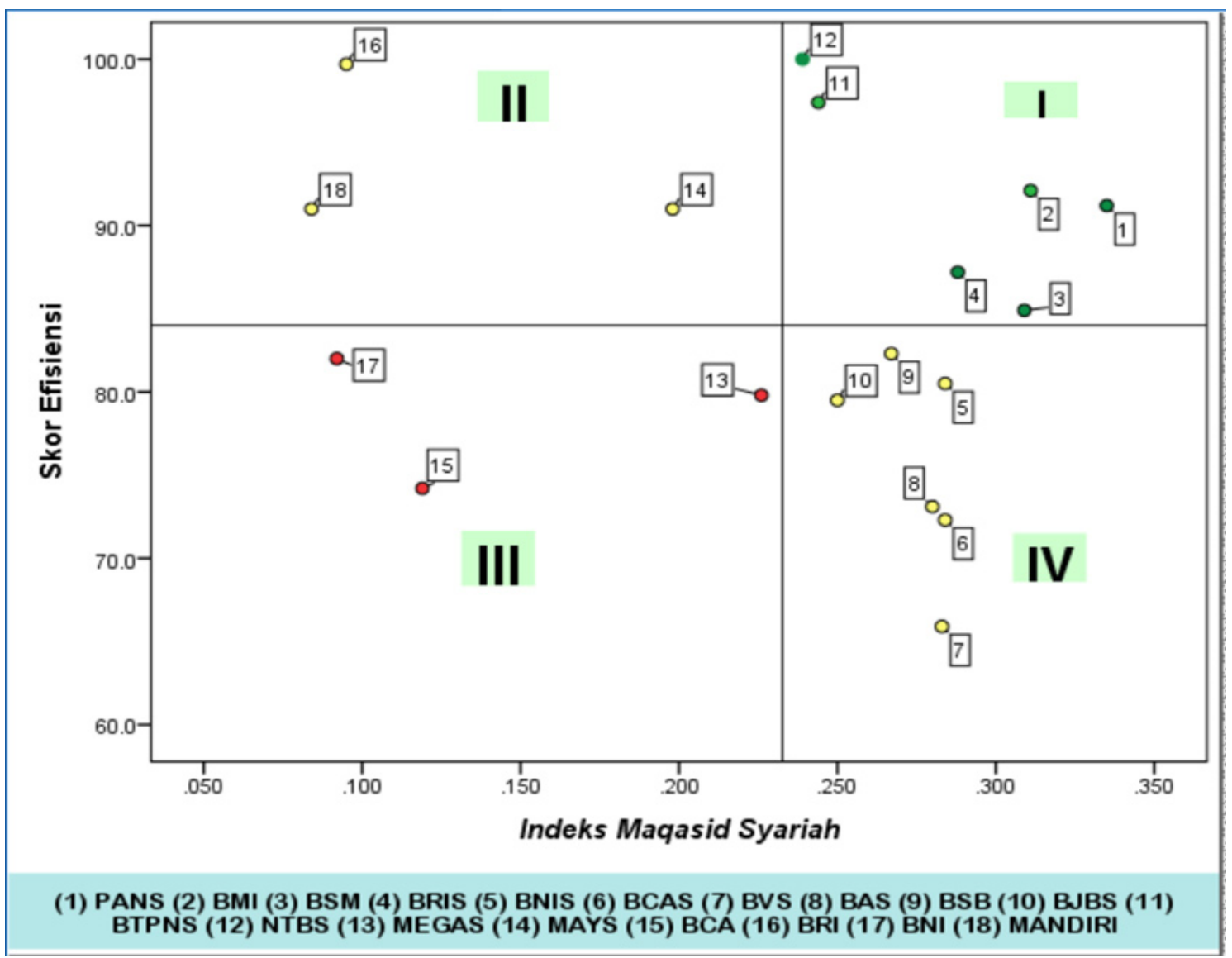

Figure 1. Comparison of the efficiency and maqasid shariah of commercial banks 


\section{Recommendations}

Based on the research results, various recommendations can be made. First, practitioners in commercial Islamic banks in particular are expected to improve not only their efficiency level, but also their implementation of maqasid shariah. The higher the efficiency, the higher the profitability. If Islamic banks can boost their profitability, this will enlarge their business scale. Finally, they should also implement maqasid sharia (Islamic) values. Second, regulators need to consider a particular kind of performance appraisal for Islamic banks through an Islamic value approach. Third, further research should analyse and identify how the maqasid shariah index affects bank efficiency.

\section{ACKNOWLEDGMENT}

This research is supported by LPDP (Indonesia Endowment Fund for Education), Ministry of Finance, Republic Indonesia. I would like to thank LPDP for providing me with the financial support during my study at School of Business, IPB University.

\section{REFERENCES}

Ahmad NH, Noor MANM. 2011. The determinants efficiency and profitability of world islamic banks. International Conference on E-business, Management and Economics IPEDR. 3, IACSIT Press, Hong Kong.

Ahmed A. 2010. Global financial crisis: An Islamic finance perspective. International Journal of Islamic and Middle Eastern Finance and Management 3(4): 306-320.

Alqahtani F, Mayes DG, Brown K. 2017. Islamic bank efficiency compared to conventional banks during the global crisis in the GCC region. J. Int. Finance, Markets Inst, Money 51: 58-74.

Antonio MS. 2001. Bank syariah: Dari teori ke praktik. Jakarta: Gema Insani Press-Tazkia Cendekia.

Antonio MS, Sanrego YD, Taufiq M. 2012. An analysis of islamic banking performance: maqashid index implementation in indonesia and jordania. Journal of Islamic Finance 1(1): 12- 29.

Ascarya, Yumanita D. 2006. Analisis efisiensi perbankan syariah di Indonesia dengan data envelopment analysis. TAZKIA Islamic Finance and Business Review 1(2): 1-27.
Ascarya, Yumanita D. 2008. Comparing the efficiency of Islamic banks in Malaysia and Indonesia. Buletin Ekonomi Moneter dan Perbankan, Oktober, 95-119.

Banker RD, Charnes A, Cooper WW. 1984. Some models for estimating technical and scale inefficiency in data envelopment analysis. Management Science 30(9): 1078-1092.

Beck T, Kunt AD, Merrouche O. 2010. Islamic vs conventional banking, business model, efficiency and stability. Policy Research Working Paper 5446: 1-42.

Brown K, Hassan MK, Skully M. 2007. Operational efficiency and performance of islamic banks. Di dalam: Hassan MK, Lewis MK, editor. Handbook of Islamic Banking. 2007. Cheltenham, UK: Edward Elgar Publishing Limited.

Chapra MU. 1993. Islam and economic development: A strategy for development with justice and stability. Pakistan: International Institute of Islamic Thought Islamabad and Islamic Research Institute, Islamabad.

Charnes A, Cooper WW, Rhodes E. 1978. Measuring the efficiency of decision making units. European Journal of Operation Research 2: 429-444.

Čihák M, Hesse H. 2010. Islamic banks and financial stability an empirical analysis. Journal of Financial Services Research 38(2): 95-113.

Coelli TJ, Rao DSP, O`Donnell CJ, Battese GE. 2005. An introduction to efficiency and productivity analysis. 2nd Ed. New York: Springer.

Debreu G. 1951. The coefficient of resource utilization. Econometrica 19(3): 273-292.

Elahi MME. 2010. The objectives and intents of islamic shari' ah as a paradigm of development strategies and policies. IIUC Studies 7: 321- 336.

Farrell MJ. 1957. The measurement of productive efficiency. Journal of the Royal Statistical Society Series A (General) 120(3): 253-290.

Firdaus MF, Hosen MN. 2013. Efisiensi bank umum syariah menggunakan pendekatan two-stage data envelopment analysis. Buletin Ekonomi Moneter dan Perbankan 167-188.

Freixas X, Rochet JC. 1998. Microeconomics of Banking. England: The MIT Press.

Ftiti Z, Nafti O, Sreiri S. 2013. Efficiency of Islamic banks during subprime crisis: evidence of gec countries. The Journal of Applied Business Research 29(1): 285-304.

Global Islamic Finance Report. 2019. Islamic finance country index 2019. http://www.gifr.net/. 
GlobeNewswire Research and Market. 2019. Global Islamic Finance Markets Report 2019: Islamic Banking is the Largest Sector, Contributing to $71 \%$, or USD 1.72 Trillion. https://www. globenewswire.com.

Hardianto DS, Wulandari P. 2016. Islamic bank vs conventional bank: intermediation, fee based service activity and efficiency. International Journal of Islamic and Middle Eastern Finance and Management 9(2): 296-311.

Hartono S, Sobari A. 2017. Sharia maqashid index as a measuring performance of islamic banking: a more holistic approach. Corporate Ownership and Control 14(2): 193-201.

Havidz SAH., Setiawan C. 2015. Bank efficiency and non-performing financing (NPF) in the indonesian islamic banks. Asian Journal of Economic Modelling 3(3): 61-79.

Hidayati N, Siregar H, Pasaribu SH. 2017. Determinant of efficiency of the islamic banking in indonesia. Buletin Ekonomi Moneter dan Perbankan 20(1): 29-47.

Ibrahim WHW, Ismail AG. 2020. Do regulation, maqasid shariah and institutional parameter improve Islamic bank efficiency? Journal of Islamic Monetary Economics and Finance 6(1): 135-162.

Imam P, Kpodar K. 2016. Islamic banking: Good for growth. Economic Modelling 59: 387-401.

Ismail F, Majid MSA, Ab. Rahim R. 2013. Efficiency of Islamic and conventional banks in Malaysia. Journal of Financial Reporting and Accounting 11(1): 92-107.

Kamarudin F, Sufian F, Nassir AMd, Anwar NAM, Hussain HI. 2019. Bank efficiency in malaysia a DEA approach. Journal of Central Banking Theory and Practice 1: 133-162.

Khalaifī RM. 2004. Maqūshid syarī'ah wa atsaruhā fi al figh al mu'āmalāt al māliyah. Kuwait: Universitas King Abdul Aziz: 8.

Kim J-Y, Haleblian J. 2011. When firms are desperate to grow via acquisition: The effect of growth patterns and acquisition experience on acquisition premiums. Administrative Science Quarterly 56: 26-60.

Majeed MT, Zanib A. 2016. Efficiency analysis of Islamic banks in Pakistan. Humanomics 32(1): 19-32.

Mezzi N. 2018. Efficiency of Islamic banks and role of governance: empirical evidence. Managerial Finance 44(5): 590-603.
Miah MD, Uddin H. 2017. Efficiency and stability: A comparative study between Islamic and conventional banks in GCC countries. Future Business Journal 3: 172-185.

Mohammed MO, Taib FMd. 2015. Developing islamic banking performance measures based on maqasid al-shariah framework: Cases of 24 selected banks. Journal of Islamic Monetary Economics and Finance 1(1): 55-77.

Mostafa MM. 2011. Modeling Islamic banks'efficiency: a non-parametric frontier approach. International Journal of Islamic and Middle Eastern Finance and Management 4(1): 7-29.

Murillo LR., Zamorano. 2004. Economic efficiency and frontier techniques. Journal of Economic Surveys 18(1): 33-77.

Olson D, Zoubi T. 2016. Convergence in bank performance for commercial and islamic banks during and after the global financial crisis. The Quarterly Review of Economics and Finance 950: 1-55.

Otoritas Jasa Keuangan. 2019. Statistika Perbankan Syariah 2019. http://www.ojk.go.id.

[P3EI] Pusat Pengkajian dan Pengembangan Ekonomi Islam, Universitas Islam Indonesia dan Bank Indonesia. 2009. Ekonomi Islam. Jakarta: Rajawali Pers.

Puteh A, Rasyidin M, Mawaddah N. 2018. Islamic banks in indonesia: analysis of efficiency. Emerald Reach Proceedings Series 1: 331-336.

Reza M, Violita ES. 2018. Pengaruh penerapan nilainilai islam terhadap kinerja bank syariah dengan menggunakan maqashid index: studi lintas negara. Jurnal Dinamika Akuntansi dan Bisnis 5(1): 17-30.

Rosman R, Wahab NA, Zainol Z. 2014. Efficiency of islamic banks during the financial crisis: an analysis of middle eastern and asian countries. Pacific-Basin Finance Journal 28: 76-90.

Rozzani N, Rahman RA. 2013. Determinants of bank efficiency: conventional versus Islamic. International Journal of Business and Management 8(14): 98-109.

Rusydiana AS, Parisi SAl. 2016. The measurement of islamic bank performance: a study using maqāshid index and profitability. Global Review of Islamic Economics and Business 4(1): 1-14.

Sealey CW, Lindley JT. 1977. Inputs, outputs, and theory of production cost at depository financial institutions. Journal of Finance 32: 1251-1266.

Sudrajat A, Sodiq A. 2016. Analisis penilaian kinerja 
bank syariah berdasarkan indeks maqāshid shari'ah (studi kasus pada 9 bank umum syariah di indonesia tahun 2015). BISNIS 4(1): 178200.

Sufian F, Kamarudin F. 2015. Determinants of revenue efficiency of Islamic banks Empirical evidence from the Southeast Asian countries. International Journal of Islamic and Middle Eastern Finance and Management 8(1): 36-63.

Sumarwan U, Hartoyo, Fahmi I. 2018. Metode riset bisnis dan konsumen: Edisi revisi. Bogor: IPB Press.

Sutawijaya A, Lestari EP. 2009. Efisiensi teknik perbankan indonesia pascakrisis ekonomi: Sebuah studi empiris penerapan model DEA. Jurnal Ekonomi Pembangunan 10(1): 49- 67.

Ullah H. 2014. Shari'ah compliance in islamic bankingan empirical study on selected Islamic banks in
Bangladesh. International Journal of Islamic and Middle Eastern Finance and Management 7(2): 182-199.

Ullah MdH, Khanam R. 2018. Whether shari'ah compliance efficiency is a matter for the financial performance the case of Islami bank Bangladesh limited. Journal of Islamic Accounting and Business Research 9(2): 183-200.

Wanke P, Azad. MDAK, Barros CP. 2016. Predicting efficiency in Malaysian Islamic banks: A twostage TOPSIS and neural networks approach. Research in International Business and Finance 36: 485-498.

Widokartiko B, Achsani NA, Beik IS. 2016. Dampak kinerja internal dan kondisi makro ekonomi terhadap profitabilitas pada perbankan. Jurnal Aplikasi Bisnis dan Manajemen 2(2): 161-171. 